\title{
Cost Minimization of Generation, Storage, and New Loads, Comparing Costs with and without Externalities
}

\author{
Lance Noel ${ }^{1,2, *}$, Joseph F. Brodie ${ }^{1}$, Willett Kempton ${ }^{1}$, Cristina L. Archer ${ }^{1}$, Cory Budischak ${ }^{3}$
}

\begin{abstract}
The goal of this research is to understand the economics of anticipated large-scale changes in the electric system. 86 million different combinations of renewable generation (wind and solar), natural gas, and three storage types (hydrogen storage, electric vehicles equipped with vehicle-to-grid (V2G) technology, and building heat) are modeled within the PJM Interconnection. The corresponding electric systems are then operated and constrained to meet the load every hour over four years. The total cost of each energy system is calculated, both with and without externalities, to find the least cost energy systems.

Using today's costs of conventional and renewable electricity and without adding any externalities, the cost-minimum system includes no renewable generation, but does include EVs. When externalities are included, however, the most cost-effective to system covers $50 \%$ of the electric load with renewable energy and runs reliably without need for either new conventional generation or purpose-built storage.

The three novel energy policy implications of this research are: (1) using today's cost of renewable electricity and estimates of externalities, it is cost effective to implement $240 \mathrm{GW}$ of renewable electricity to meet $50 \%$ of the total electric load; (2) there is limited need to construct new natural gas power plants, especially from a system-wide perspective; and (3) existing coal plants may still be useful to the energy system, and instead of being retired, should be repurposed to occasionally provide generation.
\end{abstract}

Keywords: renewable energy; electric vehicles; externalities; vehicle-to-grid; energy modeling; renewable integration 


\section{Acknowledgements}

28 The authors would like to thank the following people for the help and advice in undertaking this work: Wayne Moodie, Deniz Ozkan, Scott Baker, Jeremy Firestone, Mike Dvorak, Regina McCormack, and William Facciolo.

This work was supported in part by DOE Grant DE-EE0005366, W. Kempton, Principal Investigator.

\section{Nomenclature}

\begin{tabular}{|c|c|c|c|}
\hline Cap $_{\text {Mw/Mwh }}$ & Capital Cost per MW/MWh & CG & Conventional Generation \\
\hline $\mathrm{EH}$ & Electric Heat & EL & Electric Load \\
\hline ES & Energy Storage & ESRB & Energy Storage Range Buffer \\
\hline EV & Electric Vehicle & FOM & Fixed Operation \& Maintenance Cost \\
\hline $\mathrm{Gen}_{k}$ & $\begin{array}{l}\text { Average Annual Generation for } \\
\text { Generation Type k }\end{array}$ & GHG & Greenhouse Gas \\
\hline GIS & Geographic Information System & $\mathrm{H}$ & Health Externality Cost \\
\hline $\mathrm{H}_{2}$ & Hydrogen Storage & $\mathrm{HL}$ & Heat Load \\
\hline $\mathrm{HP}$ & Heat Pump & HS & Heat Storage \\
\hline ICE & Internal Combustion Engine & ITC & Investment Tax Credit \\
\hline LCOE & Levelized Cost of Energy & LMP & Local Marginal Prices \\
\hline METSTAT & Meteorological-Statistical Model & $\mathrm{MW}_{\mathrm{k}}$ & $\begin{array}{c}\text { Installed Power Capacity for } \\
\text { Generation Type k }\end{array}$ \\
\hline $\mathrm{MWh}_{\mathrm{k}}$ & $\begin{array}{c}\text { Installed Storage Capacity for } \\
\text { Generation Type k }\end{array}$ & $\mathrm{NGH}$ & Natural Gas Heaters \\
\hline O\&M & Operation and Maintenance & PTC & Production Tax Credit \\
\hline PUC & Public Utility Commission & PV & Photovoltaic \\
\hline$r$ & Discount Rate & RG & Renewable Generation \\
\hline RHTS & $\begin{array}{c}\text { Resistive Heating with Thermal } \\
\text { Storage }\end{array}$ & RPS & Renewable Portfolio Standard \\
\hline RREEOM & $\begin{array}{l}\text { Regional Renewable Electricity } \\
\text { Optimization Model }\end{array}$ & RTO & Regional Transmission Organization \\
\hline SCC & Social Cost of Carbon & SoC & State-of-charge \\
\hline SOFC & Solid Oxide Fuel Cell & V2G & Vehicle-to-grid \\
\hline VOM & $\begin{array}{c}\text { Variable Operation \& Maintenance } \\
\text { Cost }\end{array}$ & WRF & Wind Research \& Forecasting Model \\
\hline
\end{tabular}

\section{Introduction}

Large reductions in $\mathrm{CO}_{2}$ emissions may require shifting from fossil fuels to electric power for light vehicles and building heat, while also generating increasing fractions of electricity from fluctuating renewable sources. Previous papers have investigated the plausibility and benefits of large-scale renewable energy 
penetration. Jacobson and Delucchi (1) investigated the possibility of powering the entire world's energy demand by wind, water and solar power and concluded that, although significant investments would be required, it is plausible for wind, water, and solar to power the world's energy demand, given resource capacity and physical and material constraints. .

Focusing on the U.S. electric system, Arent et al. investigated the feasibility of large-scale renewable, finding that there are substantial benefits (without calculating the costs) of reaching $80 \%$ renewable (2) Likewise, Mai et al. calculate a pathway to $80 \%$ renewable by 2050 , finding a $30 \%$ increased cost compared to current generation cost (not including externalities) (3). Another model, SWITCH, has been used to study how the US Western generation mix would change with carbon pricing (4), also finding $80 \%$ reduction in carbon emissions by 2050. Finally, a recent study (5) compares new wind and solar generation, and hypothesizes a future national electricity market, continent-wide transmission, and balancing over a national grid, finding a $80 \%$ renewable national grid in 2030 will cost the same as average electricity costs in 2012 . Two previous studies based on the model used in this analysis (6) (7) compared fixed proportions of renewables via one price metric, and found that a significant percentage of hours could be covered with renewable energy, and that, at expected future costs, more than $90 \%$ of hours could be covered by renewable energy at a cost lower than current prices

Rather than fixing the target fraction of renewable energy, this study models a large U.S. electric system (now $165 \mathrm{GW}$ generation, with $85 \mathrm{GW}_{\mathrm{a}}$ average load), iterating to create 85,766,121 possible variants of generation, storage and new loads, then running each through 4 years of hourly operation. Building on previous literature, the costs and benefits of each of these possible energy systems are evaluated to find those that minimize the net present cost to society. An innovative aspect of this approach is that the optimal fraction of renewable energy generation is therefore an outcome, not a constraint.

For perspective, the cost minimization calculations in this article are not a reflection of current decision-making. In the United States, decisions regarding electricity systems are reviewed and approved by state public utility commissions (PUCs), which minimize only the market cost of electricity, ignoring the health and environmental external costs. Outside the PUC evaluation, other state or Federal agencies use regulatory mechanisms to reduce pollution. The model here provides a common metric to compare the minimization of only internal costs versus the minimization of all costs to society. The model does not project future population nor continuing declines in the cost of renewable generation. Rather than predicting a least-cost future, one can think of this analysis as answering the question: "If policies had been minimizing social cost, what would the energy system look like today?" Or, looking forward, the results could be a guide to the energy system if external costs are incorporated into the price of fuels.

This article models four types of new generation-land-based wind, offshore wind, solar photovoltaics (PV), and natural gas. The model also includes two new types of load (i.e., the conversion of vehicles and building heat to electricity), along with the benefits and costs of such fuel switching; secular load growth is not modeled. For possible new storage, the model includes hydrogen as purpose-built storage and two other forms of inherent end-use storage, vehicle-to-grid (V2G) electric vehicles (EVs), and electric heat storage (EH), 
with the latter two becoming available only as their associated loads do as well. Because the model includes transportation and heating sectors, most of the calculations consider changes in the societal cost of energy including displacing vehicle and heating fuels, not just electricity (some cost-minima change when both are included). Electricity, transport and building heat represent more than two thirds of carbon emissions in the U.S. (8) and have commercially ready renewable alternatives. The model, based on (6), is constrained to meet electric and heating load each hour. It models a real electric grid, the PJM Interconnection, a large US regional transmission organization (RTO), using hourly load, weather, and solar data for years 2010 through 2013.

Compared to previous studies, the work presented in this article contributes to the literature in in three novel ways. First, the model integrates electricity, storage, transportation and heating systems. In contrast, previous models only focused on the electricity system, and often ignored EVs and EH, with even fewer including V2G and heat storage. Secondly, this study models over 86 million different combinations of energy systems, compared to previous studies that reported the characteristics of one to several energy systems, allowing for comparisons across different types of energy systems. The iterative nature of the model can more precisely estimate the marginal cost of increasing renewable share of electric load and, at the same time, capture the various technological pathways of reaching a certain percentage of renewable. Lastly, this work is unique to analyze the costs of each energy system both with and without externalities and to explore the differences in the cost-minimum systems and their renewable penetration. In sum, this research analyzes a currently-existing market, adds new types of load, storage and generation, and compares cost-optima with and without externality costs. The methods are described in the Methodology and in the Supplemental Section.

\section{Methodology}

This study utilizes and modifies the Regional Renewable Electricity Economic Optimization Model (RREEOM), developed by Budischak et al. (6). The Supplemental Section describes the improvements to RREEOM's economic calculations and modeling. This study attempts to incorporate more comprehensive economic costs than original version of the model, but also makes some simplifications, see section 2.2.1 below for full discussion of assumptions. Compared with more typical economic models, this model lacks valuation of consumer preferences, the increasing marginal cost of implementation, and price elasticity. Geographically, RREEOM's data is exclusively within the PJM territory; the article does not model power transfers to and from other RTO regions, nor does the model consider deployment time constraints. Instead, the purpose of this work is to show the implications of monetizing externalities on the development of renewable energy within a large region.

\subsection{Model Inputs}

The model represents three main energy- and carbon-producing sectors: electricity generation and storage; light-duty vehicles, and building heat. For each sector, the model requires two types of inputs. First, the cost of each technology, which consists of capital costs, operation and maintenance (O\&M), and externalities. Second, in order to determine how much of each resource is needed, the hourly load and resource capacity of each technology (e.g. how much load hourly; how much wind and sun hourly) is similarly required. In overview, the model generates all possible combinations of each generation, storage, and new 
load; each combination is called an "energy system". Then the model runs each energy system for four years to determine how load is met by generation and storage, given yearly variations in wind and solar production. The method for calculating the inputs for each of the sectors is discussed next in broad terms, while the Supplemental Section gives more detials.

\subsubsection{Costs}

To calculate costs, electricity production was disaggregated into six generation types: offshore wind, land-based wind, solar, nuclear, natural gas, and coal. Offshore wind, land-based wind, solar, and natural gas were modeled as potential new capacity installations. The model does not include new nuclear and coal power plants as these are much more costly than new natural gas plants (9), and currently few or none of these are planned for new generation capacity in PJM. This is a reasonable simplification because, in fact, of the nearly $60 \mathrm{GW}$ of new generation planned in PJM over the next ten years, over $95 \%$ is either wind or natural gas (10). There are no nuclear plants on queue in the PJM territory, and planned new coal generation is about $1 \%$ of total PJM capacity (10). In the model, whenever renewable generation, plus storage, fails to meet the load, the difference is met by today's PJM conventional generation (see Figure 1 below). Coal, natural gas and nuclear together make up $89 \%$ of today's PJM power capacity and $95 \%$ of annual energy generation (11). Thus, while the total PJM electricity capacity is $186 \mathrm{GW}$, and includes wind, solar, pumped hydro, and oil, for the purposes of simplified modeling, the model's current generation includes only nuclear, coal, and natural gas, a total capacity of $165 \mathrm{GW}$. The model also ignores current renewable generation, which comprised less than $2 \%$ of annual electric energy, and less than $1 \mathrm{GW}$ of power capacity (10) during the modeled years. Economically, the model assumes that the existing PJM system does not have any capital costs, and only operating costs are considered. To model new generation and storage, the capital costs are based on 2013 estimated costs (12) (9), inclusive of transmission and interconnection costs. Wind is modeled to increase in capital cost as the lower cost sites are used up first, both for land-based and offshore wind.

Operation and maintenance (O\&M) costs were included for both existing and new installations and were divided into fixed (FOM) and variable (VOM) costs. FOM includes O\&M costs not associated with operating hours, such as scheduled maintenance, while VOM increases with greater utilization of the power plant, for example, component wear, and notably consumable materials such as fuel. Estimated FOM and VOM costs for each generation type were drawn from EIA (9) (13) (14).

Two categories of external cost were included: health and climate change. Health externalities were based on health impact studies per type of generation, drawn from three studies (15) (16) (17). Climate externalities use lifecycle GHG emission rates for each generation type (18), converted to cost using two Federal calculations: an "average" and "realistic worst case" social cost of carbon (SCC) estimates (19), SCC1 and SCC2 in the model.

Secondly, storage was divided into two types: hydrogen storage $\left(\mathrm{H}_{2}\right)$ and V2G-capable electric vehicles. Purpose-built batteries were found by Budischak et al. (6) to not be cost-competitive and therefore are not modeled here. For $\mathrm{H}_{2}$ storage, it was assumed that an electrolyzer would generate $\mathrm{H}_{2}$ in an aboveground storage tank, and associated fuel cells would convert the $\mathrm{H}_{2}$ back to electricity. Capital costs and conversion 
losses associated with $\mathrm{H}_{2}$ were based on a solid oxide fuel cell (SOFC), an electrolyzer, and a steel tank (20). On the other hand, estimating the capital cost of V2G was more complex. V2G is low-cost because it uses storage and grid connections purchased for the electric vehicle's primary purpose, transportation. A secondary purpose, electricity storage, is accomplished by adding control equipment, at minimal capital cost. Currently, most people are not choosing to buy an electric vehicle, therefore, the model calculates the added capital costs for V2G based on surveyed willingness-to-pay for an electric vehicle, with the assumption that an incentive would be required to get people to buy an EV in the first place. The needed incentives were based on a stated preference survey (21), compared to the average cost of a gasoline vehicle (22); this is added to the cost of EV purchase, reflecting the cost of adding this load and storage resource. This difference was then converted into the cost per kWh of added battery capacity. Unlike previous models, the willingness to pay for an electric vehicle in this model is heterogeneous across the population-system-wide, that means that more is paid for each additional marginal kWh of V2G storage as more EVs are added. For further details, see the Supplemental Section.

$\mathrm{H}_{2}$ storage uses no fuel, and its VOM electrical input cost is accounted for in round trip losses, not in input electricity; an additional FOM cost is based on the literature (23). For V2G storage, VOM and FOM costs are calculated in the context of the displacement of internal combustion engine (ICE) vehicles, which have been found to be more expensive to maintain. However, given the lack of data regarding EV FOM, the model conservatively assumes that there is no net change regarding FOM of EVs. On the other hand, EV VOM incurs a cost by adding load to the grid, but also a benefit in that gasoline consumption is displaced. Both of these are estimated from average miles driven per year, gasoline efficiency (24), and the current cost of gasoline, with federal and state taxes removed (25). These savings are calculated as a benefit per megawatt-hour (MWh) of EV capacity per year, thus effectively a benefit of adding V2G storage. Similarly, the externalities associated with EVs were calculated as the health benefits from reduced gasoline consumption (26) and climate change mitigation benefits (27) (19). Likewise, the cost of replacing batteries due to degradation, based on estimated future battery pack prices (28), is also included in EV VOM. Unlike EVs for V2G storage, $\mathrm{H}_{2}$ storage does not directly cause any externalities, nor does it directly displace any significant externalities.

For large scale renewable penetration, recent models show that the most cost-effective electrical systems will be configured so that generation exceeds load during certain hours, which for wind, would be more likely to occur in the winter (6) (29). It has been proposed that this excess generation can be used for heat (7) (6). The model assumes a hybrid system comprising of a heat pump (HP) and resistive heating with thermal energy storage (RHTS), both with their own benefit; HP provides high efficiency while RHTS has low capital costs and allows compact, long-term heat storage (due to much higher temperature) (7). Similarly to V2G storage, increased penetration of EH would displace natural gas heaters (NGH), which comprise about $75 \%$ of all non-EHs in PJM (30). The capital cost of each technology is based on (7). The FOM of an HP/RHTS hybrid system is less than the FOM cost of a NGH system, implying a FOM savings as HP/RHTS penetration increases (7). Meanwhile, the model includes the sole added component of VOM for heating as the fuel cost of natural gas. While EH will add to load, it will also displace natural gas consumption, thus, the VOM cost is based on natural gas fuel savings (31). Likewise, the externalities are based on the reduction of health damages due to natural gas combustion (32)(33), and reduction of climate change emissions (34), (19). 


\subsubsection{Resource Assessment and Production}

A resource assessment for PJM is required in order to set the maximum capacity of each new generation and storage resource in the model. The resource maximum is used to set an upper limit for iterating through possible electrical systems, as the model builds each type of generation from zero to the maximum capacity. Production is computed hourly, and compared to load for each hour over a four-year period, from 2010 to 2013. The resource maximum for new natural gas generation and $\mathrm{H}_{2}$ storage has no natural limit as they are man-made. Thus, based on preliminary model runs, their maximum resource limit was set well above what would be cost effective.

Land-based wind capacity was determined based on state-by-state data, using a report of potential wind capacity in each state, given sufficient wind speeds and exclusion areas (35). Since some states are not entirely within PJM, these state numbers were adjusted to reflect wind capacity within PJM's territory (36). These calculations yield a total $201 \mathrm{GW}$ capacity within PJM territory. Moreover, to account for spatial variability, the model assigns areas into one of three capacity factor ranges (see the Supplemental Section) and utilizes the windiest areas first. Next, the hourly capacity factors, i.e. the ratio of the actual production over the maximum capacity are calculated base on four years of actual hourly wind generation data in PJM from 2010 to 2013, obtained as part of a joint UD-PJM project (37). Because the vast majority of wind turbines operating during these four years have a smaller rotor diameter than wind turbines being installed today (38) (39), and because the model seeks to accurately reflect today's technology, the capacity factors were accordingly adjusted to reflect current turbine technology and practices. See the Supplemental Section. After this adjustment, the average capacity factor across all of PJM would have been 0.351 if today's larger rotor diameter wind turbines had been deployed. Hourly land-based wind generation was obtained as the product of the hourly adjusted capacity factor by thte total capacity.

Rooftop solar capacity was also determined on a statewide basis (40). To determine the proportion of states only partially covered by the PJM territory, Geographic Information System (GIS) data were used to find the relative household density within the PJM service area of each of these states (41), and compared to the GIS solar capacity (42), (40), resulting in a maximum capacity of $96 \mathrm{GW}$ in the PJM territory. Hourly solar data were gathered from all the locations within NREL's Meteorological-Statistical (METSTAT) solar model that would fall under PJM jurisdiction. At each location, the solar radiance was modeled in watt-hours per square meter $\left(\mathrm{Wh} / \mathrm{m}^{2}\right)$ based on the METSTAT model (43). This was converted into an hourly capacity factor by dividing modeled radiance by $1,000 \mathrm{Wh} / \mathrm{m}^{2}$, the ideal solar radiance for maximum capacity, and then multiplying by 0.80 to account for losses, resulting in an average capacity factor over the four years of 0.134. Since solar capacity did not change significantly across the PJM territory, this same capacity factor was used in all PJM locations, and the same solar capacity was aggregated and treated as a single solar plant.

For offshore wind, the maximum capacity in PJM was based on areas that were available for offshore wind development adjacent to the PJM states, from Virginia to New Jersey, with exclusion areas removed (37). Based on this work, $78 \mathrm{GW}$ of offshore wind could be developed and connected to the PJM area. This capacity was divided into two areas in this study, based on water depth, with the deeper areas requiring greater capital costs, primarily due to increased foundation costs and associated financing (44). Hourly generation of offshore 
wind over the four years was determined using the Weather Research \& Forecasting (WRF) model. From hourly wind speeds and the power curve of a model turbine (the REpower $5 \mathrm{MW}$ ) the production of offshore wind power minus losses was calculated. As a benchmark, the average capacity factor over the four years was 0.424 .

The maximum V2G capacity is based on total motor vehicle registration within the PJM territory (45) (41). The number of vehicles was multiplied by average battery capacity per car (21) to obtain the maximum potential V2G storage capacity in PJM of 1,950 GWh. Likewise it was assumed that for every EV there would be, on average, a $10 \mathrm{~kW}$ bidirectional charger (some smaller; others larger), resulting in a maximum power capacity of $521 \mathrm{GW}$. From the perspective of the model, the total capacity of V2G is treated as one single aggregate battery. This battery was constrained each hour by three conditions: first, it must never go below its range buffer for unexpected trips of $20 \%$ state-of-charge (SoC); second, its capacity is limited by the amount of time the vehicle is being driven and thus disconnected from the charger, decreasing the capacity on average by 7\% (46); and third, the aggregate battery "loses" energy for driving, approximated as if it were a leakage rate at $0.86 \%$ of its maximum $\mathrm{kWh}$ capacity each hour.

Lastly, the maximum heating capacity "resource" is based on the maximum heat load, as calculated by (7). The authors also calculated the hourly heating load over the four years. For each electrical system, heat storage is filled at times of excess electricity and emptied as needed for building heat (see Figure 1 below).

\subsection{Description of the RREEOM Model v. 2.0}

The model is based on RREEOM (6), though significantly modified. The original RREEOM was constrained to meet hourly electrical load from renewable generation, storage, and back-up thermal generation, in the least costly mix possible. To capture the range of possible energy systems, Budischak et al. (6) created 1.6 billion different possible electricity systems, with 70 different possible values for each of the five input variables. The present model modifies several key aspects, including the incorporation of EV driving behavior, minimum SoC, driving load, thermal load from heat demand, and the possibility of new natural gas development. Because these additions factorially increase the number of combinations, the updated RREEOM steps through 21, rather than 70, increments of possible values for each of the six input variables (solar, landbased wind, offshore wind, $\mathrm{H}_{2}, \mathrm{~V} 2 \mathrm{G}$, and $\mathrm{EH}$ ). This creates $21^{6}=85,766,121$ (86 million) combinations of new generation, storage, electric vehicles and electric heating.

The model iteratively creates each energy system, then compares that system's renewable electricity generation for each hour to the hourly electricity load within PJM from 2010 to 2013 (47), 35,064 hours in total. During those four years, the maximum actual PJM electrical load was $158 \mathrm{GW}$, and the average hourly load was $86 \mathrm{GW}_{\mathrm{a}}$. Furthermore, the model also keeps track of the hourly heat load (7), which had a maximum of $180 \mathrm{GW}_{\mathrm{t}}$ with an average of $52 \mathrm{GW}_{\mathrm{t}}$.

When testing each energy system during the four years, if renewable generation at a given hour is less than the combined electric and thermal load, the model will use all available storage to meet those loads. Any remaining load will be met by generation from the current PJM system (as a simplification, only current thermal plants), dispatched according to lowest hourly cost, and as constrained by estimated ramp rates. If 
262 there is still more load, the model will then construct and then use as many new natural gas generators as needed. In the Supplemental Section, the assumption that building new natural gas is more expensive than using existing generation is tested, and it is concluded that it is cheaper to dispatch the current PJM system first, justifying the above-described simplified algorithm. Conversely, if renewable generation at a given hour exceeds electricity load, it will then be used to meet heat load via heat pumps. If there is remaining excess renewable generation, it will be put into electric storage, if any excess remains after that, it is put into high temperature heat storage via electric resistance. If excess generation still remains, it will be spilled. It should be noted that the spilled excess generation in practice would likely be sold in inter-regional markets, but this is outside the scope of the current model; as a consequence, the model underestimates the value of excess generation. The logical operation of the model is illustrated in Figure 1.

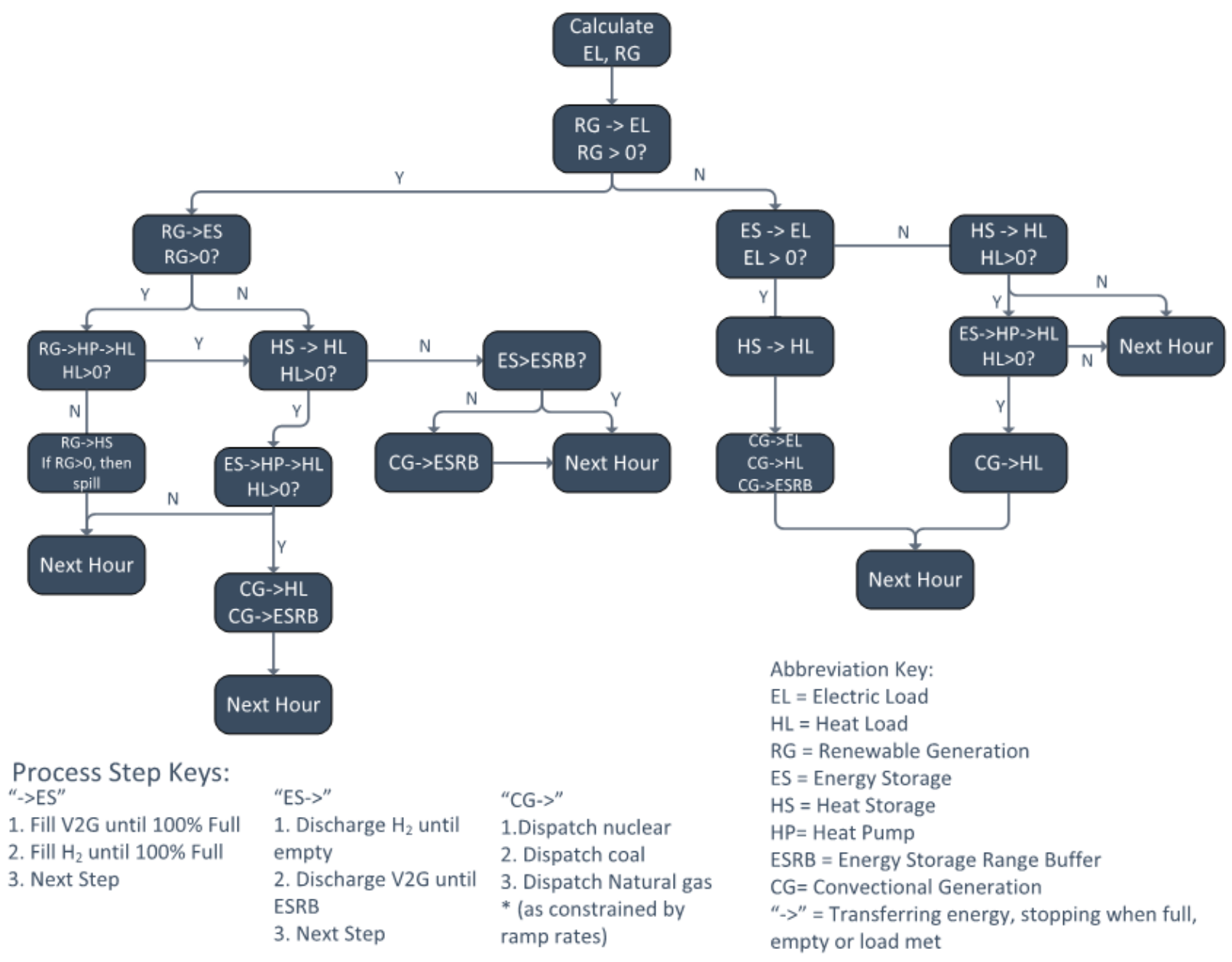




\subsubsection{Model Assumptions}

The model makes several simplifying assumptions. The model assumes that there is perfect transmission (the "copper plate" assumption). It assumes that no energy will be imported or exported to other connected TSOs; ignores reserve requirements, within-hourly fluctuations of load and generation, retirements of existing power plants, and does not include the possibility of demand-side management. Demand-side management, including demand-response and energy efficiency, were not included so as not to rely on assumptions of the amount and cost of demand-side management; as well, their omission makes interpretation of the results more direct. In reality, demand-side management will be useful and cost-effective for matching generation to load in the actual implementation of renewable generation, but this is outside the scope of this paper.

These simplifications are also discussed in Budischak, et al., (6) at 62-63. They allow the model to show what an electricity system would look like and how it could work with various penetrations of renewable energy; it is not intended to model sub-hourly dispatch decisions. Furthermore, with large amounts of storage, over- and under-generation due to ramp rates, within-hour fluctuations of load, and reserve requirements would be addressed by dispatch of quick storage which is plentiful for other reasons in all the low-cost systems (48).

One important implication of the model's large increase in load from today, yet not allowing export from the wind-rich Great Plains, is that limited and increasingly expensive wind within PJM is used. By contrast, Budischak et al. (6) assumed that wind generation could be drawn from outside the then-PJM footprint, resulting in three findings quite different from the present study: it was cost-effective to build $90 \%$ renewables (with externalities included), building $99 \%$ renewables, although more costly, required much less conventional generation than seen here, and storage was both normallly full and utilized much more than here.

Likewise, similar to the previous model (6), this model aggregates and simplifies the spatial aspects of the electricity grid, connecting all generation and load. While this oversimplifies the balancing challenges of renewable electricity integration, there is also an abundance of quick storage geographically dispersed present in the low-cost systems. The computionally-intensive spatial consideration of the electricity grid is outside the scope of the work presented here, and should be developed in future work. Relatedly, another implication concerns the model's simplifying assumption of uniform prices within the entire PJM area, whereas in fact, "Locational Marginal Prices" (LMPs) are higher in PJM's East and North, and wind energy costs are much less in the Great Plains, to the West of PJM. Thus, some additional thermal generation might be built in areas with higher LMPs, and offshore wind and solar would be more competitive in the Northeast, than shown in the results based on PJM average costs. Further, the low-cost onshore wind capacity would not be limited to 201 $\mathrm{GW}$, implying cost-effective results at higher renewable penetration.

\subsubsection{Cost Calculation of the Model Output}

The model calculates the cost for each system in net present value over a 25-year lifespan, using a 3\% discount rate (a social discount rate, appropriate to show the cost to society) (49). Note that the model uses 
net present value rather than the more conventional metric of cost, levelized cost of energy (LCOE) in cents/kWh; either works equally well to find minimum cost systems. These costs are calculated based on the inputs, as previously discussed. The model calculates the cost as if these hypothetical energy systems are built in the beginning of each run, and thus underestimates the build-out constraints and lower costs due to learning curves of renewable energy deployment. The purpose of this paper is not to show how or at what pace to develop energy systems, but rather what energy system the nation would have developed, if minimizing total social costs. One novelty of the analysis is the ability to vary the extent to which externalities affect cost minimization, allowing for policy comparisons. As noted, costs for each energy system are calculated for four different cost metrics, varying by the addition of external costs. For each cost metric, the least-cost system is foundas one minimizes Equation 1 below.

Equation 1. 25 Year Net Present Cost Calculation

$$
\text { Cost }=M W_{k} * \operatorname{Cap}_{M W_{k}}+M W h_{k} * \operatorname{Cap}_{M W_{h}}+\sum_{i=1}^{25} \frac{M W_{i, k} * F O M_{k}+G e n_{i, k} *\left(V O M_{k}+H_{k}+S C C_{k}\right)}{(1+r)^{i}}
$$

Where all symbols are defined in the Nomenclature Table, for generation type $k$ for year $i$

\section{Results}

\subsection{Minimum-cost electric systems}

The costs for each of the 85,766,121 energy systems were calculated using four cost metrics: market cost without any externalities ("Market"), then market cost plus health externalities (labelled "M+Health"), then adding to those an "Average Case" social cost of carbon (the "M+H+SCC1" cost), and alternatively substituting for SCC1, a "Realistic Worst Case" social cost of carbon (19) ("M+H+SCC2"). Table 1 shows the power capacity and energy production mix for each minimum cost solution, based on each of the four cost metrics. For example, using the $\mathrm{M}+\mathrm{Health}$ cost metric to pick the lowest cost of the 86 million energy systems, the minimum-cost system has $4.8 \mathrm{GW}$ of solar capacity and $121 \mathrm{GW}$ of wind, no new electric heat but $235 \mathrm{GW}$ of new EV, while retaining $156 \mathrm{GW}$ conventional generation, for a total of $282 \mathrm{GW}$ generation capacity (compared to $165 \mathrm{GW}$ today). This capacity produces $101 \mathrm{GW}_{\mathrm{a}}$ to meet load (compared to $86 \mathrm{GW}_{\mathrm{a}}$ today), the greater capacity and generation needed due to additional EV load.

Table 1. Power Capacity, Electricity Produced, storage, and new loads in each the four Minimum-cost Energy Systems.

\begin{tabular}{|c|c|c|c|c|c|c|c|c|}
\hline & \multicolumn{4}{|c|}{$\begin{array}{l}\text { Power Capacity in GW } \\
\quad \text { (now } 165 \mathrm{GW})\end{array}$} & \multicolumn{4}{|c|}{$\begin{array}{l}\text { Electric Energy Produced in } \mathrm{GW}_{\mathrm{a}} \\
\qquad\left(\text { now } 86 \mathrm{GW}_{\mathrm{a}}\right)\end{array}$} \\
\hline & $\begin{array}{c}\text { Market } \\
\text { cost }\end{array}$ & $\begin{array}{c}\text { M+ } \\
\text { Health }\end{array}$ & $\begin{array}{c}M+H+S C \\
C 1\end{array}$ & $\begin{array}{c}M+H+S C \\
C 2\end{array}$ & $\begin{array}{c}\text { Market } \\
\text { cost }\end{array}$ & $\begin{array}{c}\text { M+ } \\
\text { Health }\end{array}$ & $\begin{array}{c}M+H+S C \\
C 1\end{array}$ & $\begin{array}{c}M+H+S C \\
C 2\end{array}$ \\
\hline
\end{tabular}




\begin{tabular}{|c|c|c|c|c|c|c|c|c|}
\hline Solar PV & 0 & 4.8 & 33.9 & 77.4 & 0 & 0.7 & 4.54 & 10.4 \\
\hline Land Based Wind & 0 & 121 & 191.6 & 201.7 & 0 & 41 & 58 & 61.1 \\
\hline Offshore Wind & 0 & 0 & 0 & 19.5 & 0 & 0 & 0 & 8.25 \\
\hline $\begin{array}{r}\text { Conventional } \\
\text { Generation }\end{array}$ & 181 & 156 & 153.5 & 159.5 & 111 & 59 & 50 & 43 \\
\hline Sum of generation & 181 & 282 & 379.0 & 458 & 111 & 101 & 113 & 123 \\
\hline Storage & \multicolumn{4}{|c|}{ Capacity (GW) } & \multicolumn{4}{|c|}{ Discharged to grid $\left(G W_{a}\right)$} \\
\hline V2G EVs & 235 & 235 & 365 & 417 & 0 & 0.65 & 2.1 & 3.2 \\
\hline $\mathrm{H}_{2}$ Storage & 0 & 0 & 0 & 0 & 0 & 0 & 0 & 0 \\
\hline New Loads & \multicolumn{4}{|c|}{ Load power capacity (GW) } & \multicolumn{4}{|c|}{ Load energy consumed (GW $)$} \\
\hline EV charging & 235 & 235 & 365 & 417 & 7.6 & 7.6 & 11.8 & 13.4 \\
\hline $\begin{array}{r}\text { Electric Heat } \\
\text { (of } 180 \mathrm{GW} ; 52 \mathrm{GWa} \text { ) }\end{array}$ & 180 & 0 & 126 & 180 & 52 & 0 & 37 & 52 \\
\hline
\end{tabular}

Several trends are seen across Table 1. Generally, as more external costs are considered, systems with more renewable energy are picked as least expensive, conventional generation capacity declines modestly, and conventional production declines substantially. Examining each minimum-cost system (each column), first, selecting by market cost only, the minimum-cost system builds no renewable electricity. This result conveys that without monetizing externalities (and without existing tax credits), it is not cost effective to build GW-scale renewable generation. Thus, the model with Market-cost optimization approximately replicates current decisions by utilities and PUCs, which until recently built only minimal amounts of renewables. The market cost-only metric does develop substantial EH and EVs. Thus, while fuel saving alone does not incentivize renewable electricity, it does incentivize the implementation of EVs and EH.

In contrast, the $\mathrm{M}+$ Health metric selects $121 \mathrm{GW}$ of land-based wind and $4.8 \mathrm{GW}$ of solar PV, together producing $42 \mathrm{GW}_{\mathrm{a}}$ of electricity, about half of electricity consumption. Implicit in this jump up is that there is a threshold effect for renewable electricity, where a great deal is built above a certain price of conventional generation, but none below that price. Though this energy system develops large amounts of renewable energy, almost all goes directly to load; only $1.8 \%$ of generation is spilled, thus there is insufficient excess generation to economically power EH and little need for storage.

$\mathrm{M}+\mathrm{H}+\mathrm{SCC} 1$ almost doubles renewable capacity to $220 \mathrm{GW}$, and accelerates fuel switching, converting $70 \%$ of all NGH's to $\mathrm{EH}$ and $70 \%$ of all ICE vehicles to EVs. Note that these more complete externality costs lead to a system with renewable generation capacity that is substantially larger than load, thus there are more hours of excess production than with Market or M+Health alone, effectively lowering the cost of electricity for 
$359 \mathrm{EV}$ and $\mathrm{EH}$. This combined effect illustrates the value of modeling renewable generation each hour along with 360 new flexible loads.

361 Figure 2 shows the interaction among renewable generation, electric and heat storage, and 362 conventional generation in the $\mathrm{M}+\mathrm{H}+\mathrm{SCC} 1$ minimum-cost energy system over each hour of the four modeled 363 years. Renewable generation ranges from 2.9 to $179 \mathrm{GW}$ and conventional generation is required throughout 364 the four years for both electric and heating loads. Heat storage is recharged only when excess generation and 365 lower loads occurs, and only $0.8 \%$ of the total annual heat load is met via heat storage. 

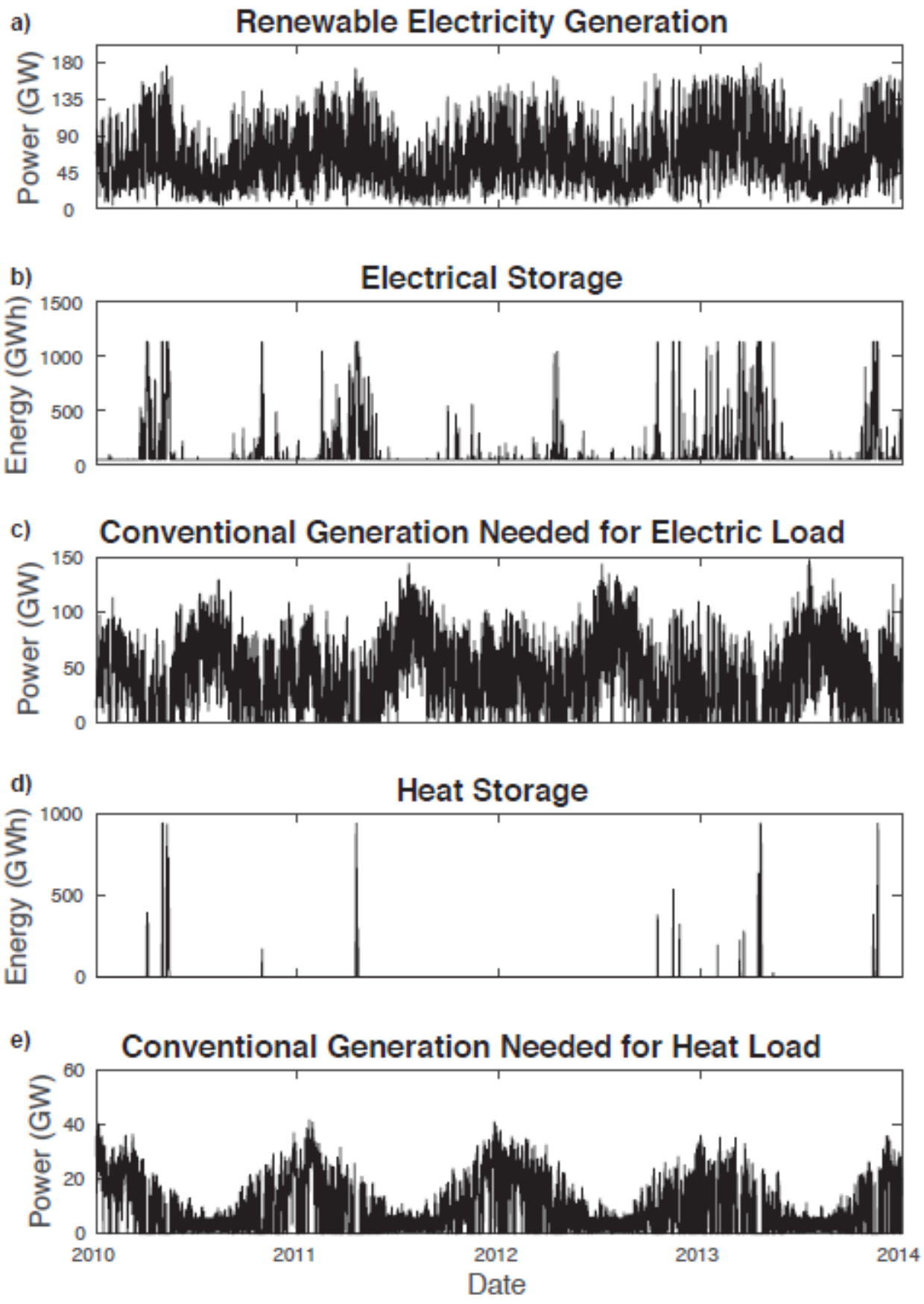

Figure 2. Hourly Generation and Storage State-of-Charge for the Minimized Energy System under the $\mathrm{M}+\mathrm{H}+\mathrm{SCC} 1$ metric a) Renewable Electricity Generation, b) Energy in Electrical Storage, c) Dispatched Conventional Generation Used to Meet Electrical Load (excluding heating), d) Energy in Heat Storage, e) Dispatched Conventional Generation Used to Meet Heat Load 
Finally, $\mathrm{M}+\mathrm{H}+\mathrm{SCC} 2$ is dominated by $299 \mathrm{GW}$ of renewable capacity, as well as converting $100 \%$ of buildings to $\mathrm{EH}$ and $80 \%$ of all vehicles to $\mathrm{EVs} . \mathrm{M}+\mathrm{H}+\mathrm{SCC} 2$ is the only system to implement any offshore wind, and also the only to build the maximum amount of land-based wind, $201 \mathrm{GW}$. Because electric load has increased from EVs and EHs, despite $299 \mathrm{GW}$ of renewable electricity, this energy system requires $159.5 \mathrm{GW}$ of conventional electricity capacity.

Across all four minimum-cost energy systems there are several consistent trends. Each requires substantial conventional generation capacity. Despite new loads in all systems, all minimum-cost energy systems (except the Market energy system) require less conventional capacity and less conventional energy generation than the current PJM grid. None of the minimum-cost energy systems that include externalities require the construction of any new conventional generation, despite new load and hundreds of GWs of renewable electricity capacity. Moreover, the average energy used from conventional generation decreases as externalities are monetized, though only down to a lowest of $43 \mathrm{GW}_{\mathrm{a}}$. Correspondingly, none of the minimumcost energy systems implement any hydrogen storage, and use very limited amounts of V2G storage to meet load. That is, it is cheaper to utilize the current legacy generation of PJM and storage inherent in EVs and EH when renewable generation is insufficient rather than to build extra storage or new conventional generation.

Table 2 shows the cost of implementing each of the four minimum-cost electricity grids incrementally to today's cost. These additional costs are calculated for the four cost metrics for each minimized grid for the point of comparison. One way to read Table 2 is if the "Market" column (columns are how the minimum cost system is picked) and the market row (the metric that calculates row's cost), this intersection being the method and metric of PUCs today - the cost of electricity is close to today's actual wholesale price - just $1.3 \mathrm{c} / \mathrm{kWh}$ higher. However, society actually has to pay these external costs, so, continuing down the column, the actual cost to society is 5.7 to $10.9 \mathrm{c} / \mathrm{kWh}$ above today's wholesale price. Conversely, using the lowest cost electric system under $\mathrm{M}+\mathrm{H}+\mathrm{SCC} 2$ (the right most column), the social cost is the cheapest-an additional $7.7 \mathrm{c} / \mathrm{kWh}$ (lowest number on bottom row). Yet from a PUC perspective (i.e., only considering market costs, that is, only reading the top row) the $\mathrm{M}+\mathrm{H}+\mathrm{SCC} 2$ system would not be least expensive, it would add 5.4 cents per $\mathrm{kWh}$.

While storage is used only at limited times (Fig. 2), it still plays an important cost-reducing role. Excluding all forms of electrochemical storage, the $\mathrm{M}+\mathrm{H}+\mathrm{SCC} 1$ cost-minimized energy system would only construct $175 \mathrm{GW}$ of renewable electricity (51 GW less than the central results), and cost $\$ 230$ billion more than the central results, which utilize $365 \mathrm{GW}$ and 1,369 GWh V2G storage capacity, costing $\$ 742$ billion to implement. To replace V2G with the same capacity of purpose-built hydrogen storage, however, it would cost society an additional $\$ 416$ billion. To the extent storage reduces the cost of the energy system, V2G is a costoptimum way of providing storage.

Table 2. Additional electric Cost per kWh of each Minimum-Cost Energy System (in cents per kWh added to today's market price). Columns are the cost metric used to pick the minimum cost system. Rows describe which costs are included in the $\mathrm{c} / \mathrm{kWh}$ figures in that row. External cost savings of load shifts from fuel to electricity 
are included in picking the minimum cost system (columns) but not in the calculation of electricity cost increments (rows).

\begin{tabular}{|c|c|c|c|c|c|}
\hline \multicolumn{2}{|c|}{} & \multicolumn{4}{|c|}{ Metric used to choose minimum-cost system } \\
\cline { 3 - 6 } \multicolumn{2}{|c|}{} & Market Cost & M+Health & M+H+SCC1 & M+H+SCC2 \\
\hline \multirow{2}{*}{$\begin{array}{c}\text { Metric for } \\
\text { electricity } \\
\text { cost }\end{array}$} & Market Cost & $\mathbf{1 . 3}^{1}$ & 4.2 & 4.7 & 5.4 \\
\cline { 2 - 6 } $\begin{array}{c}\text { increment } \\
(\mathrm{C} / \mathrm{kWh})\end{array}$ & $\mathrm{M}+$ Health & $5.7^{2}$ & $\mathbf{6 . 4}$ & $6.2^{2}$ & 6.5 \\
\cline { 2 - 6 } & $\mathrm{M}+\mathrm{H}+\mathrm{SCC} 1$ & 7.6 & 7.2 & 6.8 & 6.9 \\
\hline
\end{tabular}

1. This electricity cost is higher than today's grid (despite no added renewable electricity) because the total load has increased due to higher levels of EVs and EHs.

2. Note that two electric cost increments (marked with note 2) are unexpectedly cheaper per kWh than the diagonals, due to the fact that these cost increments include the cost of new generation but not the externality savings from EV and HV fuel switch from fuels to electricity.

\section{Trends across Energy Systems}

Next the costs of all energy systems modelled are compared. Figure 3 compares the costs of all energy systems (not only minimum-cost ones) across increasing amounts of load covered by renewables. The figure also illustrates that the maximum amount of renewables, regardless of cost, was $92.6 \%$. This maximum is lower than the $99.9 \%$ calculated in Budischak, et al. (6)due to today's larger PJM territory, new loads from EVs and $\mathrm{EH}$, and the limitation on wind capacity-all of which led to a low wind production to load ratio.

Whereas Figure 3a shows the costs for all energy systems, 3b shows only the cost-minimized systems at each renewable percentage, the two lines distinguishing cost indexes (Market versus $\mathrm{M}+\mathrm{H}+\mathrm{SCC} 1$ ). The low points of each line in Figure $3 \mathrm{~b}$ correspond to the single selected electric systems of Table 1 , that is, the minimum cost system includes near-zero renewables if the cost-minimum is picked by market cost only, but renewables cover $50 \%$ of load for $\mathrm{M}+\mathrm{H}+\mathrm{SCC} 1$ (see the corresponding energy columns of Table 1 ). The $\mathrm{M}+\mathrm{H}+\mathrm{SCC} 1$ curve is very flat--for example to move from the $50 \%$ cost minimum to $70 \%$ renewables, it costs only $2.3 \%$ more. By contrast, the market cost curve rises monotonically with more renewables. Both curves become exponentially more expensive to about 90\% renewables, because PJM renewable resources are more scarce, in poorer resource areas, thus more expensive, given the restriction to locate them within PJM territory only. This exponential increase highlights the limitation of the model; in reality, if PJM were to aim for more than $85 \%$ renewable in the near-term, other techniques would be utilized, such as demand-response, importing wind from the Midwest, efforts to increase energy efficiency, or building other, less common types of renewable electricity. 
432

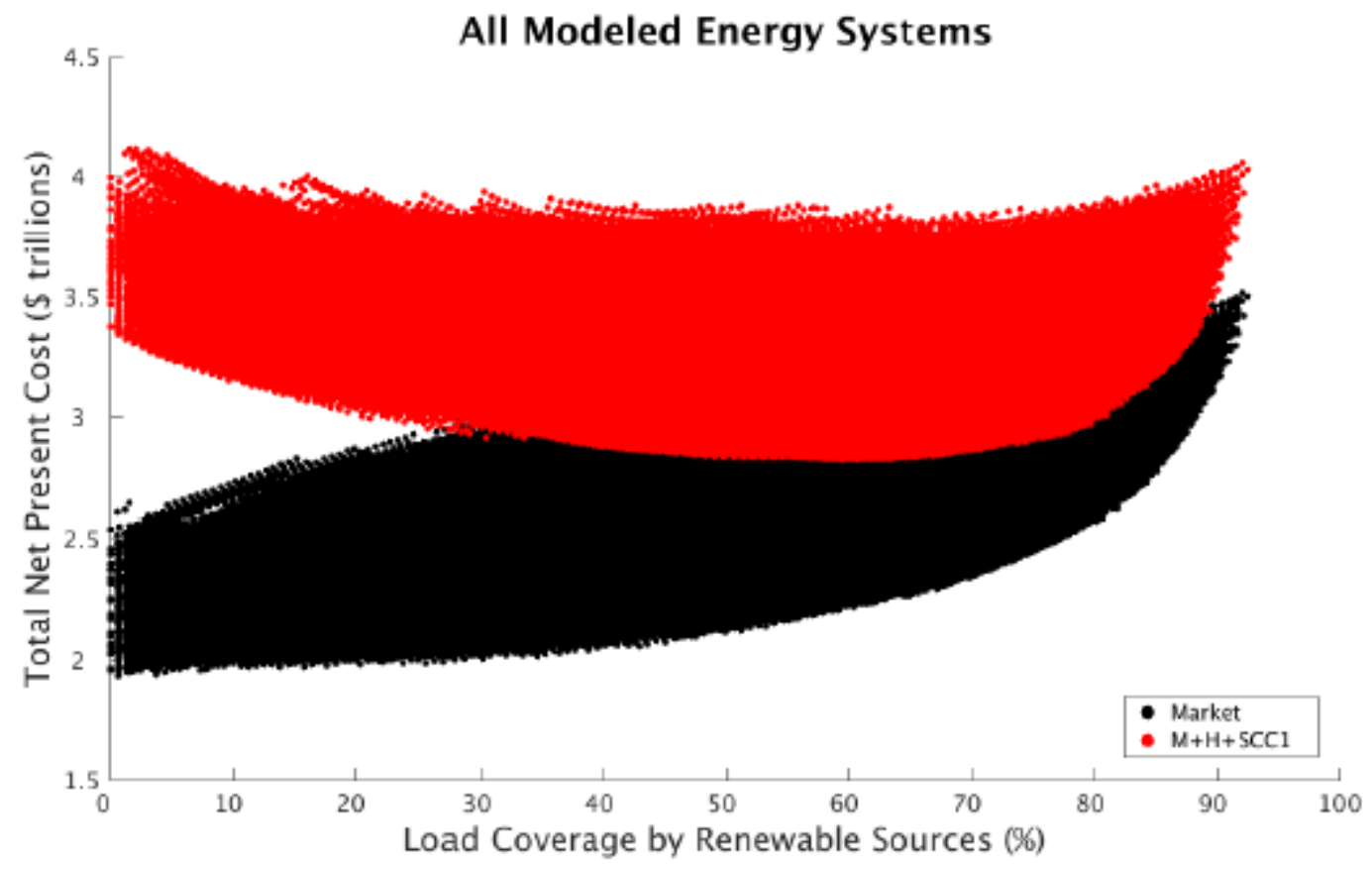

$433 \quad b)$

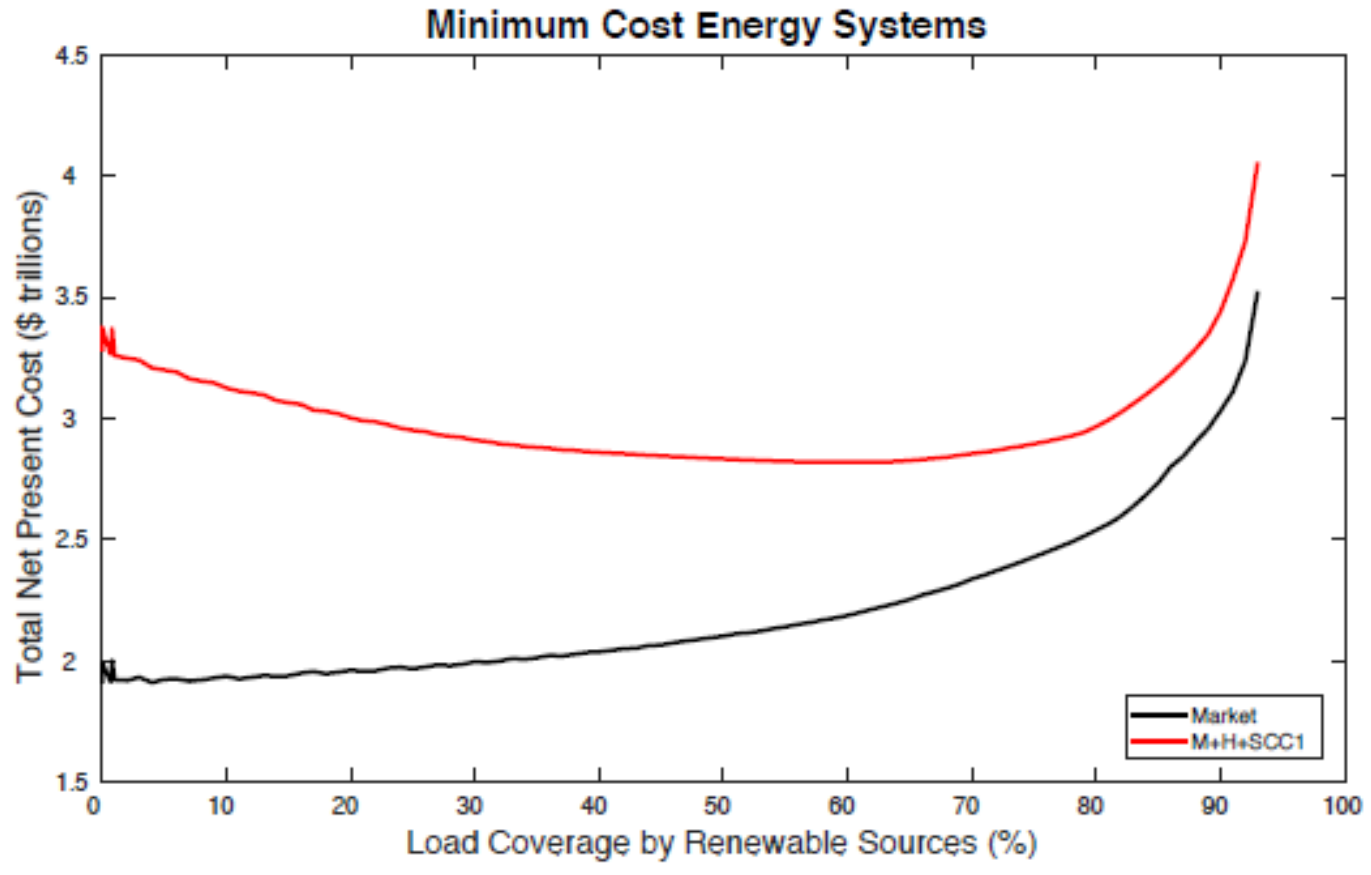


Figure 3. Comparing energy systems by Renewable Share of Load (x-axis) to Net Present Cost (y-axis) Cost is given both as market (no externalities) and as $\mathrm{M}+\mathrm{H}+\mathrm{SCC} 1$. a) Cost of every Energy System at each percentage of load covered by Renewables. b) Minimum Cost Energy System at Each Percentage of Load covered by Renewables

As another view of cost-minima, Figure 4 shows how land-based wind versus solar (the two most utilized renewables) affect cost, assuming zero implementation of other technologies. Figure 4a shows Market cost (via color) and $4 \mathrm{~b}$ shows $\mathrm{M}+\mathrm{H}+\mathrm{SCC} 1$ cost (note, $4 \mathrm{a}$ and $4 \mathrm{~b}$ use different color scales but both use red for highest cost). In $4 a$, the lowest cost region is the extreme lower left, with any increases in solar or wind increasing cost, and highest costs at the upper right maxima. Figure $4 \mathrm{~b}$, measuring by $\mathrm{M}+\mathrm{H}+\mathrm{SCC} 1$ shows that from the origin, increasing either solar or wind reduces cost. Wind has a much larger effect--if wind is held at zero, no amount of solar alone significantly reduces the cost. Conversely, if half the wind resource is built (120 $\mathrm{GW})$, cost is dramatically reduced and much solar can be built without increasing cost. The general shape of $4 a$ versus $4 \mathrm{~b}$ has a lesson in the "optics" of renewables -- if one only considers market cost, it appears that anything more than small amounts ( $10 \%)$ of renewables quickly increases costs, whereas the true cost as in $4 b$, is substantially higher if large amounts of wind are not built; adding solar causes a very small but non-zero reduction in social cost.
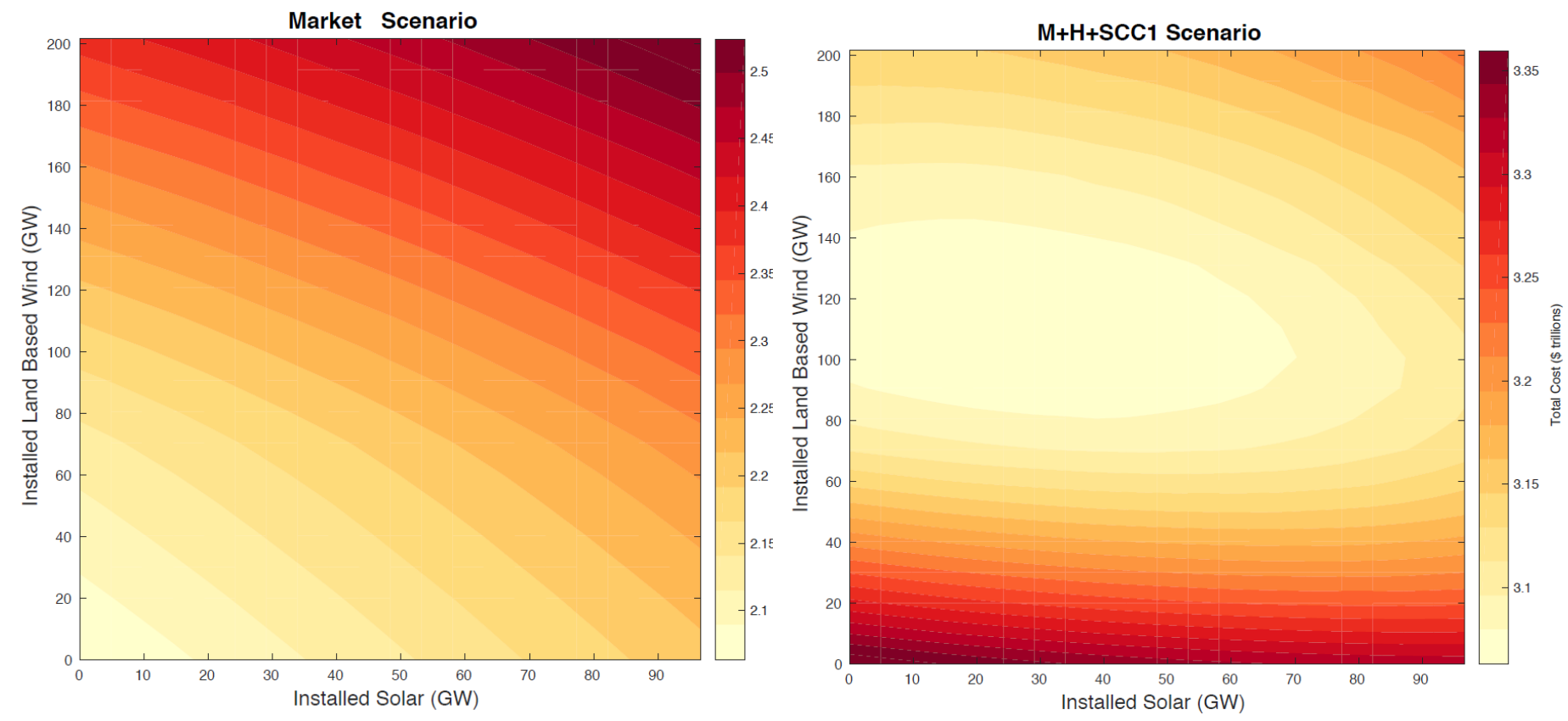
Figure 4. The Relative Impact on net present cost $\left(\$ \times 10^{12}\right)$ of energy systems, comparing all combinations of land-based wind and solar. a) Market with cost metric shown by color. b) M+H+SCC1 with cost metric shown by color.

\section{Sensitivity Analyses}

Beginning from the central results shown in Figure 2, four alternative cost inputs were substituted to determine how much input assumptions affected the results (additional sensitivity analyses are in the Supplemental Section). Table 3 summarizes the resulting minimum-cost systems based on both Market and $\mathrm{M}+\mathrm{H}+\mathrm{SCC} 1$ cost metrics.

Table 3. Comparison Of Alternative Assumptions on Power Capacity Mixes (in GW)

\begin{tabular}{|c|c|c|c|c|c|c|c|c|}
\hline & Solar & $\begin{array}{l}\text { Offshor } \\
\text { e Wind }\end{array}$ & $\begin{array}{l}\text { Land- } \\
\text { based } \\
\text { Wind }\end{array}$ & V2G & $\begin{array}{c}\text { Hydrog } \\
\text { en }\end{array}$ & $\begin{array}{c}\text { Total } \\
\text { Conventional } \\
\text { (now 165) }\end{array}$ & $\begin{array}{l}\text { New } \\
\text { Natural gas } \\
\text { generation }\end{array}$ & $\begin{array}{c}\text { Electric } \\
\text { Heat }\end{array}$ \\
\hline $\begin{array}{l}\text { Maximum } \\
\text { Resource } \\
\text { Capacity }\end{array}$ & 97 & 77.5 & 201 & 521 & $\infty$ & $\infty$ & $\infty$ & 180 \\
\hline $\begin{array}{l}\text { Central Results } \\
\text { Market } \\
\mathrm{M}+\mathrm{H}+\mathrm{SCC} 1\end{array}$ & $\begin{array}{c}0 \\
33.9\end{array}$ & $\begin{array}{l}0 \\
0\end{array}$ & $\begin{array}{c}0 \\
191\end{array}$ & $\begin{array}{l}235 \\
365\end{array}$ & $\begin{array}{l}0 \\
0\end{array}$ & $\begin{array}{c}180 \\
153.5\end{array}$ & $\begin{array}{c}17 \\
0\end{array}$ & $\begin{array}{l}180 \\
126\end{array}$ \\
\hline $\begin{array}{l}\text { 7\% Disc. Rate } \\
\text { Market } \\
\mathrm{M}+\mathrm{H}+\mathrm{SCC} 1\end{array}$ & $\begin{array}{l}0 \\
0\end{array}$ & $\begin{array}{l}0 \\
0\end{array}$ & $\begin{array}{c}0 \\
101\end{array}$ & $\begin{array}{c}104 \\
156.5\end{array}$ & $\begin{array}{l}0 \\
0\end{array}$ & $\begin{array}{l}162 \\
148\end{array}$ & $\begin{array}{l}0 \\
0\end{array}$ & $\begin{array}{c}0 \\
36\end{array}$ \\
\hline $\begin{array}{l}2030 \text { Cap. Costs } \\
\text { Market } \\
\mathrm{M}+\mathrm{H}+\mathrm{SCC} 1\end{array}$ & $\begin{array}{c}0 \\
53\end{array}$ & $\begin{array}{c}0 \\
19\end{array}$ & $\begin{array}{c}0 \\
201\end{array}$ & $\begin{array}{l}496 \\
496\end{array}$ & $\begin{array}{l}0 \\
0\end{array}$ & $\begin{array}{l}191 \\
154\end{array}$ & $\begin{array}{c}26 \\
0\end{array}$ & $\begin{array}{l}180 \\
144\end{array}$ \\
\hline $\begin{array}{l}\text { With PTC/ITC } \\
\text { Market } \\
\text { M+H+SCC1 }\end{array}$ & $\begin{array}{c}0 \\
77\end{array}$ & $\begin{array}{l}0 \\
0\end{array}$ & $\begin{array}{c}20 \\
201\end{array}$ & $\begin{array}{l}231 \\
365\end{array}$ & $\begin{array}{l}0 \\
0\end{array}$ & $\begin{array}{l}171 \\
153\end{array}$ & $\begin{array}{l}6 \\
0\end{array}$ & $\begin{array}{l}180 \\
153\end{array}$ \\
\hline $\begin{array}{l}2030 \text { Cap + PTC } \\
\text { Market } \\
\text { M+H+SCC1 }\end{array}$ & $\begin{array}{c}0 \\
72.5\end{array}$ & $\begin{array}{c}0 \\
27\end{array}$ & $\begin{array}{c}20 \\
201\end{array}$ & $\begin{array}{l}496 \\
496\end{array}$ & $\begin{array}{l}0 \\
0\end{array}$ & $\begin{array}{l}180 \\
165\end{array}$ & $\begin{array}{c}15 \\
0\end{array}$ & $\begin{array}{l}180 \\
180\end{array}$ \\
\hline
\end{tabular}

465

466

467

468

469

The first sensitivity analysis was to change the discount rate from a social discount rate (3\%) to a commercial discount rate (7\%). The discount rate is used to convert future costs and benefits to their present value. In comparison to the central results, using a higher discount rate leads to a minimum-cost energy system with $120 \mathrm{GW}$ less renewable electricity with $\mathrm{M}+\mathrm{H}+\mathrm{SCC} 1$, and 150-200 GW less of V2G (in both M and 
$\mathrm{M}+\mathrm{H}+\mathrm{SSC} 1$ ). This happens because renewable electricity and transport generally have higher upfront costs yet the future benefits of fuel savings and future damage reduction are less valuable with a higher discount rate.

The second sensitivy analysis uses 2030 capital costs for new technologies, based on the mean of published estimates for the future capital costs of solar (50) (51) (52) (3) (53) (54), land-based wind (50) (51) (55) (3) (56), offshore wind (50) (57) (55) (3), and EV lithium ion batteries (58) (59) (60) (61)(Fuel cost increases in 2030 were not included). The minimum-cost energy system without externalities differs only in having substantially more EVs, due to substantially lower battery costs. These results, taken together with the central results finding large-scale EV adoption to be cost-effective, and imply that the barrier to EV implementation in the near future will not be the cost of technology, but rather consumer willingness to drive EVs. If the model is correctly capturing consumer preferences, social aspects of EVs should be the focus of any EV incentive. Unlike EVs, renewables may require market mechanisms such as monetizing externalities or direct renewable policies, as this sensitivity analysis suggests that reduced technology costs alone may not encourage renewable energy development to the socially-optimal level. This finding seems more pessimistic than current conditions in the U.S. Great Plains (outside PJM), where currents costs of wind are below cost of conventional generation, and where wind is approximately half of new generation (39).

The U.S. Production Tax Credit (PTC) and the Investment Tax Credit (ITC), are current incentives for renewable electricity development. However, the model finds that the PTC and ITC alone lead to only $20 \mathrm{GW}$ of renewable generation at market cost, versus almost $280 \mathrm{GW}$ if pricing includes external costs. While the PTC and ITC would encourage some renewable electricity, without the monetization of externalities, like 2030 capital costs, it is not enough to encourage similar amounts of renewable electricity as would including externalities. Adding the PTC andITC to the 2030 capital costs reduction (last row in Table 3 ) also does not produces substantially more renewabledevelopment, again showing that including externalities is the most powerful incentive.

\section{Conclusions}

These conclusions address system operation and three policy observations. The scenario with highest renewables (458 GW capacity and $123 \mathrm{GW}_{\text {a }}$ production) and high new loads (597 GW new plug capacity and 65.4 $\mathrm{GW}_{\mathrm{a}}$ average load), works as a reliable system and provides assured power despite weather fluctuations. This least cost system $(\mathrm{M}+\mathrm{H}+\mathrm{SCC} 2)$ builds out more renewables than needed to meet current types of loads, with excess going into both $\mathrm{EV}$ and $\mathrm{EH}$, and some periods of generation deficit supplied by discharge from EV. A notable finding is that this system is reliable without either new generation or purpose-built storage, while noting the model's spatial simplification, especially in regards to transmission and balancing. The high stability without any purpose-built storage suggests that, if land-based wind were not limited to the PJM footprint, the model may have found that the least-cost system would have had substantiallly more renewables, as did (6).

As the first policy-related conclusion, using today's costs plus externalities, it is cost-effective both to implement $240 \mathrm{GW}$ of renewable electricity capacity to meet $50 \%$ of total electric load, and to convert $70 \%$ of building heat to electricity and $70 \%$ of light vehicles to EVs. In the current policy environment, PSC and business decisions are based only on market cost—separate environmental policies, such as a "Renewable 
507 Portfolio Standard" (RPS), mandate a minimum amount of renewables. Current RPSes in PJM states require an 508 average $18 \%$ by 2023 (62). --In contrast, the model finds that $50 \%$ is the PJM cost-optimum. These results 509 would support policies such as far more ambitious RPS targets in a shorter time frame than today's, or a more 510 complete accounting of costs in societal decisions.

511 Secondly, the results indicate that with 50\% renewable energy, there is limited or no need to construct 512 either new power plants or purpose-built storage. Although one commonly reads in the media that these are 513 necessary for even modest percentages of renewables, the hourly model results show that there is always 514 sufficient power and that it is substantially cheaper, to use the current legacy generation of PJM along with the 515 storage inherent in new fuel replacement technologies (EV and EH) to absorb excess generation and to fill in 516 generation lulls. New natural gas generation may play a local, supplementary role in PJM's future, such as 517 decreasing transmission congestion. However, the results suggest that actually building the $41 \mathrm{GW}$ of new 518 natural gas plants that are currently in PJM's generation queue (10) is not needed and is not cost-effective to 519 society.

Thirdly, the model finds that existing conventional thermal plants can still be useful in an external-cost

522 factor under $\mathrm{M}+\mathrm{H}+\mathrm{CCS} 1$ versus 0.61 under market costs only. Nevertheless, their existing power capacity 523 appears useful in a high-renewables system, to fill in long wind lulls that would strain storage. For example, 524 PJM is currently planning the retirement of over $20 \mathrm{GW}$ of coal through 2019 (10) based on production cost 525 and emissions; it may be desirable to evaluate retirements not only on the current metric weighted toward 526 operating cost, but to also retain some plants picked for low standby costs, maintaining them for occasional 527 use as reserves. 
531

532

533

534

535

536

537

538

539

540

541

542

543

544

545

546

547

548

549

550

551

552

553

554

555

556

557

558

559

560

561

562

563

564

\section{References}

1. Jacobson MZ, Delucchi MA. Providing all global energy with wind, water, and solar power, Part I: Technologies, energy resources, quantities and areas of infrastructure, and materials. Energy Policy. 2011 Mar;39(3):1154-69.

2. Arent D, Pless J, Mai T, Wiser R, Hand M, Baldwin S, et al. Implications of high renewable electricity penetration in the U.S. for water use, greenhouse gas emissions, land-use, and materials supply. Appl Energy. 2014 Jun;123:368-77.

3. Mai T, Mulcahy D, Hand MM, Baldwin SF. Envisioning a renewable electricity future for the United States. Energy. 2014 Feb;65:374-86.

4. Nelson J, Johnston J, Mileva A, Fripp M, Hoffman I, Petros-Good A, et al. High-resolution modeling of the western North American power system demonstrates low-cost and low-carbon futures. Energy Policy. 2012 Apr;43:436-47.

5. MacDonald AE, Clack CTM, Alexander A, Dunbar A, Wilczak J, Xie Y. Future cost-competitive electricity systems and their impact on US CO2 emissions. Nat Clim Change [Internet]. 2016 Jan 25 [cited 2016 Jan 27]; Available from: http://www.nature.com/doifinder/10.1038/nclimate2921

6. Budischak C, Sewell D, Thomson H, Mach L, Veron DE, Kempton W. Cost-minimized combinations of wind power, solar power and electrochemical storage, powering the grid up to $99.9 \%$ of the time. J Power Sources. 2013 Mar;225:60-74.

7. Pensini A, Rasmussen CN, Kempton W. Economic analysis of using excess renewable electricity to displace heating fuels. Appl Energy. 2014 Oct;131:530-43.

8. EPA. Inventory of U.S. Greenhouse Gas Emissions and Sinks: 1990-2013 [Internet]. Washington, D.C.; 2015 Apr [cited 2016 Feb 23] p. 564. Available from: http://www.epa.gov/climatechange/ghgemissions/usinventoryreport.html

9. EIA. Updated Capital Cost Estimates for Utility Scale Electricity Generating Plants [Internet]. Washington, D.C.: U.S. Department of Energy; 2013 Apr p. 201. Available from: http://www.eia.gov/forecasts/capitalcost/pdf/updated_capcost.pdf

10. Monitoring Analytics, LLC. State of the Market Report for PJM 2014 [Internet]. Monitoring Analytics; 2015 [cited $2015 \mathrm{Jul} 24$ ]. Available from:

http://www.monitoringanalytics.com/reports/PJM_State_of_the_Market/2014.shtml

11. Monitoring Analytics, LLC. State of the Market Report for PJM: 2013 [Internet]. Monitoring Analytics; 2014 p. 444. Available from: http://www.monitoringanalytics.com/reports/PJM_State_of_the_Market/2013.shtml

12. World Energy Council. World Energy Perspective: Cost of Energy Technologies [Internet]. London, UK: World Energy Council, Bloomberg New Energy Finance; 2013. Available from: 
https://www.worldenergy.org/wpcontent/uploads/2013/09/WEC_J1143_CostofTECHNOLOGIES_021013_WEB_Final.pdf

13. EIA. Electricity Data Browser [Internet]. 2014 [cited 2014 Apr 3]. Available from: http://www.eia.gov/electricity/data/browser/\#/topic/15?agg=2

14. EIA. Electric Power Annual 2012 [Internet]. Washington, D.C.: U.S. Department of Energy; 2013. Available from: https://www.eia.gov/electricity/annual/archive/03482012.pdf

15. Epstein PR, Buonocore JJ, Eckerle K, Hendryx M, Stout III BM, Heinberg R, et al. Full cost accounting for the life cycle of coal: Full cost accounting for the life cycle of coal. Ann N Y Acad Sci. 2011 Feb;1219(1):7398.

16. McCubbin D, Sovacool BK. Quantifying the health and environmental benefits of wind power to natural gas. Energy Policy. 2013 Feb;53:429-41.

17. Sundqvist T. What causes the disparity of electricity externality estimates? Energy Policy. 2004 Oct;32(15):1753-66.

18. Moomaw W, Burgherr P, Heath G, Lenzen M, Nyboer J, Verbruggen A. Annex II: Methodology. In: IPCC Special Report on Renewable Energy and Climate Change Mitigation [Internet]. Cambridge, UK and New York, NY, USA; 2011. Available from: http://srren.ipcc-wg3.de/report/IPCC_SRREN_Annex_II.pdf

19. Interagency Working Group on the Social Cost of Carbon. Technical Support Document: Technical Update of the Social Cost of Carbon for Regulatory Impact Analysis Under Executive Order 12866 [Internet]. Washington, D.C.: United States Government; 2013 [cited 2016 Feb 17]. Available from: https://www.whitehouse.gov/sites/default/files/omb/inforeg/social_cost_of_carbon_for_ria_2013_upda te.pdf

20. Schoenung S. Economic Analysis of Large-Scale Hydrogen Storage for Renewable Utility Applications [Internet]. Albuquerque, New Mexico: Sandia National Labortories; 2011 Aug p. 41. Report No.: SAND2011-4845. Available from: http://prod.sandia.gov/techlib/access-control.cgi/2011/114845.pdf

21. Hidrue MK, Parsons GR, Kempton W, Gardner MP. Willingness to pay for electric vehicles and their attributes. Resour Energy Econ. 2011 Sep;33(3):686-705.

22. U.S. Bureau of Economic Analysis. Table 7.2.5S Auto and Truck Unit Sales, Production, Expenditures, and Price [Internet]. 2014 [cited 2014 Dec 9]. Available from: http://www.bea.gov/iTable/iTable.cfm?ReqID=12\&step=1\#reqid=12\&step=3\&isuri=1\&1203=55

23. Steward D, Saur G, Penev M, Ramsden T. Lifecycle Cost Analysis of Hydrogen Versus Other Technologies for Electrical Energy Storage [Internet]. Golden, Colorado: NREL; 2009 p. 59. Available from: http://www.nrel.gov/docs/fy10osti/46719.pdf

24. U.S. Department of Transportation. Annual Vehicle Distance Traveled in Miles and Related Data [Internet]. Highwas Statistics 2011. 2014 [cited 2014 Jan 15]. Available from: http://www.fhwa.dot.gov/policyinformation/statistics/2012/vm1.cfm 
600

601

602

603

604

605

606

607

608

609

610

611

612

613

614

615

616

617

618

619

620

621

622

623

624

625

626

627

628

629

630

25. EIA. Table EN1. Federal and State Motor Fuels Taxes [Internet]. 2014 [cited 2014 Aug 14]. Available from: http://www.eia.gov/petroleum/marketing/monthly/pdf/mgt.pdf

26. von Stackelberg K, Buonocore J, Bhave PV, Schwartz JA. Public health impacts of secondary particulate formation from aromatic hydrocarbons in gasoline. Env Health. 2013;12:13.

27. EPA. Average Carbone Dioxide Emissions Resulting from Gasoline and Diesel Fuel. [Internet]. Washington, D.C.: Office of Transportation and Air Quality; 2005 Feb. Report No.: EPA420-F-05-001. Available from: http:\\nepis.epa.gov/Exe/ZyPURL.cgi?Dockey=P1001YTF.TXT

28. U.S. Department of Energy. EV Everywhere: Grand Challenge [Internet]. Washington, DC: Office of Energy Efficiency and Renewable Energy; 2014 p. 16. Report No.: DOE/EE-1024. Available from: http://energy.gov/sites/prod/files/2014/02/f8/eveverywhere_road_to_success.pdf

29. Heide D, Greiner M, von Bremen L, Hoffmann C. Reduced storage and balancing needs in a fully renewable European power system with excess wind and solar power generation. Renew Energy. 2011 Sep;36(9):2515-23.

30. EIA. "2009 RECS Survey Data [Internet]. Residential Energy Consumption Survey. 2013 [cited 2014 Aug 14]. Available from: http://www.eia.gov/consumption/residential/data/2009/

31. EIA. Natural Gas Prices [Internet]. 2014 [cited 2014 Aug 15]. Available from: http://www.eia.gov/dnav/ng/ng_pri_sum_dcu_nus_m.htm.

32. EPA. Emissions Factors \& AP 42, Compilation of Air Pollutant Emission Factors [Internet]. 2014 [cited 2014 Aug 31]. Available from: http://www.epa.gov/ttn/chief/ap42/index.html

33. Levy JI, Baxter LK, Schwartz J. Uncertainty and Variability in Health-Related Damages from Coal-Fired Power Plants in the United States. Risk Anal. 2009 Jul;29(7):1000-14.

34. EIA. Carbon Dioxide Emissions Coefficients [Internet]. 2013 [cited 2014 Aug 15]. Available from: http://www.eia.gov/environment/emissions/co2_vol_mass.cfm.

35. U.S. Department of Energy. Wind Resource Potential [Internet]. 2011 [cited 2014 Mar 15]. Available from: http://www.windpoweringamerica.gov/windmaps/resource_potential.asp

36. NREL. Wind Maps [Internet]. Dynamic Maps, GIS Data, \& Analysis Tools. 2014. Available from: http://www.nrel.gov/gis/wind.html

37. Archer CL, Simao HP, Kempton W, Powell WB, Dvorak MJ. The challenge of integrating offshore wind power in the U.S. electric grid. Part I: Wind forecast error. Submitt Renew Energy. 2016;

38. AWEA. AWEA Market Database Pro [Internet]. AWEA Resources. 2013 [cited 2014 Jun 17]. Available from: http://www.awea.org/Resources/Content.aspx?ItemNumber=5728\&navltemNumber=5776 
39. Wiser R, Bolinger M. 2013 Wind Technologies Market Report [Internet]. Washington, D.C.: Lawrence Berkeley National Laboratory, U.S. Department of Energy; 2014 p. 95. Available from: http://eetd.Ibl.gov/sites/all/files/lbnl-6809e.pdf

40. Lopez A, Roberts B, Heimiller D, Blair N, Porro G. US renewable energy technical potentials: A GIS-based analysis [Internet]. NREL; 2012 [cited 2016 Feb 23]. Available from: http://dspace.bhos.edu.az/jspui/handle/123456789/1093

41. U.S. Census Bureau. TIGER/Line Shapefiles Pre-joined with Demographic Data [Internet]. Geography. 2014 [cited 2014 Mar 20]. Available from: https://www.census.gov/geo/maps-data/data/tiger-data.html

42. NREL. Solar Data [Internet]. Dynamic Maps, GIS Data, \& Analysis Tools. 2014. Available from: http://www.nrel.gov/gis/data_solar.html

43. NREL. National Solar Radiation Data Base 1991-2010 Update [Internet]. 2010. Available from: http://rredc.nrel.gov/solar/old_data/nsrdb/1991-2010/

44. Samoteskul K, Firestone J, Corbett J, Callahan J. Changing vessel routes could significantly reduce the cost of future offshore wind projects. J Environ Manage. 2014 Aug;141:146-54.

45. U.S. Department of Transportation. State Motor Vehicle Registrations [Internet]. Highway Statistics Series 2012. 2014 [cited 2015 Jan 15]. Available from: http://www.fhwa.dot.gov/policyinformation/statistics/2012/mv1.cfm

46. Pearre NS, Kempton W, Guensler RL, Elango VV. Electric vehicles: How much range is required for a day's driving? Transp Res Part C Emerg Technol. 2011 Dec;19(6):1171-84.

47. PJM. Hourly Load Data [Internet]. 2014. Available from: http://www.pjm.com/markets-andoperations/energy/real-time/loadhryr.aspx

48. Simao HP, Powell WB, Archer CL, Kempton W. The challenge of integrating offshore wind power in the U.S. electric grid. Part II: Simulation of electricity market operations. Rev Renew Energy [Internet]. 2016; Available from: http://energysystems.princeton.edu/Papers/SimaoMAOWIT_SmartISO_v16_April292015.pdf

49. Interagency Working Group on the Social Cost of Carbon. Technical Support Document: Social Cost of Carbon for Regulatory Impact Analysis Under Executive Order 12866 [Internet]. United States Government; 2010 Feb p. 51. Available from: http://www3.epa.gov/otaq/climate/regulations/scc-tsd.pdf

50. Schroder A, Kunz F, Meiss J, Mendelevitch R, von Hirschhausen C. Current and Prospective Costs of Electricity Generation Unitl 2050 [Internet]. DIW Berlin; 2013 Jul p. 94. Available from: https://www.diw.de/documents/publikationen/73/diw_01.c.424566.de/diw_datadoc_2013-068.pdf

51. Elliston B, MacGill I, Diesendorf M. Least cost $100 \%$ renewable electricity scenarios in the Australian National Electricity Market. Energy Policy. 2013 Aug;59:270-82. 
677

678

679

680

681

682

683

684

685

686

687

688

689

690
52. Feldman D, Barbose G, Margolis R, James T, Weaver S, Darghouth N, et al. Photovoltaic System Pricing Trends: Historical, Recent and Near-Term Projectsion, 2014 Edition [Internet]. NREL/PR-6A20-62558 presented at; 2014 Sep 22 [cited 2016 Feb 23]. Available from: http://www.nrel.gov/docs/fy14osti/62558.pdf

53. Bosetti V, Catenacci M, Fiorese G, Verdolini E. The future prospect of PV and CSP solar technologies: An expert elicitation survey. Energy Policy. 2012 Oct;49:308-17.

54. Hernández-Moro J, Martínez-Duart JM. Analytical model for solar PV and CSP electricity costs: Present LCOE values and their future evolution. Renew Sustain Energy Rev. 2013 Apr;20:119-32.

55. IEA. Global EV Outlook 2015 [Internet]. Paris: OECD; 2015. Available from: http://www.iea.org/evi/Global-EV-Outlook-2015-Update_1page.pdf

56. Wiser R, Lantz E, Hand M. The past and future cost of wind energy. Natl Renew Energy Lab Gold CO Rep No NRELTP-6A20-53510 [Internet]. 2012 [cited 2016 Feb 22]; Available from: http://www.nrel.gov/docs/fy12osti/54526.pdf

57. Valpy B, English P. Future renewable energy costs: offshore wind [Internet]. KIC InnoEnergy; 2014. Available from: http://www.kic-innoenergy.com/wpcontent/uploads/2014/09/KIC_IE_OffshoreWind_anticipated_innovations_impact.pdf

58. Cluzel C, Douglas C. Cost and performance of EV batteries. Cambridge, UK: Element Energy; 2012 Mar.

59. Catenacci M, Verdolini E, Bosetti V, Fiorese G. Going electric: Expert survey on the future of battery technologies for electric vehicles. Energy Policy. 2013 Oct;61:403-13.

60. Loisel R, Pasaoglu G, Thiel C. Large-scale deployment of electric vehicles in Germany by 2030: An analysis of grid-to-vehicle and vehicle-to-grid concepts. Energy Policy. 2014 Feb;65:432-43.

61. McCrone A. Electric Vehicle Battery Prices Down $14 \%$ Year on Year [Internet]. Bloomberg New Energy Finance; 2012. Available from: https://www.newenergyfinance.com/PressReleases/view/210

62. DSIRE. Summary Maps: Programs [Internet]. DSIRE Programs. 2016 [cited 2016 Feb 23]. Available from: http://programs.dsireusa.org/system/program/maps 